\title{
FLORISTIC, DIVERSITY AND SPATIAL DISTRIBUTION OF TREE SPECIES IN A DRY FOREST IN SOUTHERN BRAZIL
}

\author{
FREITAS, W. K. ${ }^{{ }^{*}}-$ MAGALHÃES, L. M. S. ${ }^{2}-$ VIVÈS, L. R. ${ }^{1}$ \\ ${ }^{I}$ Postgraduate Program in Environmental Technology - PGTA - Fluminense Federal University \\ - UFF. Av. dos Trabalhadores, 420, 27.255-125, Vila Santa Cecília, Volta Redonda, RJ, Brasil \\ (e-mail:lisevives@yahoo.com.br)
}

${ }^{2}$ Department of Environmental Sciences and the Postgraduate Program in Sustainable Development Practices - PPGPDS - Rural Federal University of Rio de Janeiro - UFRRJ, Rod. BR-465, km 7,23851-970, Seropédica, RJ, Brasil

(e-mail:l.mauro@terra.com.br)

*Corresponding author

e-mail: wkfreitas@gmail.com; tel: +55-24-2107-3434

(Received $2^{\text {nd }}$ Jul 2016; accepted $11^{\text {th }}$ Oct 2016)

\begin{abstract}
This study was conducted in a fragment of deciduous seasonal forest (DSF), located between the municipalities of Piratuba and Ipira, Santa Catarina. The objective was to evaluate the floristic composition and the successional stage through the ecological groups, the Shannon diversity index $\left(\mathrm{H}^{\prime}\right)$ and the dispersal syndromes of species, also using the $\mathrm{H}^{\prime}$ and the McGinnies index (IGA) to determine the pattern of spatial distribution of species. 14 transects were installed, each with $1,000 \mathrm{~m}^{2}$, considering all trees with Diameter at Breast Hight $(\mathrm{DBH}) \leq 4.0 \mathrm{~cm}$. In total, 2,125 individuals were sampled, belonging to 113 species and 34 families. Myrtaceae and Fabaceae were the families with the highest species richness, with $14.2 \%$ and $11.5 \%$, respectively. Euphorbiaceae and Lauraceae added approximately $25 \%$ of the individuals. The most abundant species were Actiniostemon concolor (Spreng.) Müll. Arg (6.9\%) and Luehea divaricata Mart. (6.7\%). The ecological group of the pioneers totaled $40 \%$ of the individuals and $36.3 \%$ of the species. The zoochoric syndrome accounted for just over $60 \%$ of individuals and species. The $\mathrm{H}^{\prime}$ was 3.92 nats. ind $^{-1}$ and the Pielou evenness $(\mathrm{J})$ was 0.82 . The IGA revealed that only over $40 \%$ of the species and $60 \%$ of the individuals showed a clumped dispersion pattern. The community is on successional transition phase, from the initial to the intermediate stage. In this scenario, management measures adopted for the microscale could be implemented in order to preserve this important repository for diversity. The application of McGinnies index can be of great use in conservation and forest management, as its interpretation may contribute to the development of restoration methods of degraded areas, enrichment of forest remnants, germplasm conservation and other activities.
\end{abstract}

Keywords: Atlantic Forest; biodiversity; forest ecology; McGinnies index; phytosociology

\section{Introduction}

The Atlantic Forest originally extended from Rio Grande do Norte to Rio Grande do Sul, also covering inland portions of Brazil, Argentina and Paraguay, totaling approximately $12 \%$ of the Brazilian territory (Ribeiro et al., 2009; Fundação SOS Mata Atlântica and INPE - Instituto Nacional de Pesquisas Espaciais, 2011).

However, the industrial and agricultural development, associated with urban expansions, has generated a reduction of more than $80 \%$ of its original forest cover (Ribeiro et al., 2009). Today, the forest remnants are scattered in different sizes and exposed to many different disorders (Colombo and Joly, 2010). Therefore, the Atlantic Forest was framed among 25 global hotspots, that is, areas with high 
biodiversity, high rate of endemism and at the same time, under strong anthropogenic impacts (Santos et al., 2012).

In the state of Santa Catarina, the Atlantic Forest originally covered about $80 \%$ of its surface area, but today the native forest cover is about $30 \%$ of it (Vibrans et al., 2008). Particularly, the original seasonal dry forests areas have suffered intense deforestation process, in order that, currently, the sum of the fragments coverage of the same size or smaller than 50 ha represent only $14 \%$ of this original forest typology (Gasper et al., 2013).

According to Freitas and Magalhães (2012), the floristic analysis provides important information about the classification and taxonomic distribution of a plant community and also about ecological attributes of species, such as: diversity, dispersal syndromes, and ecological groups, among others.

The species are organized in different patterns of distribution, as follows: clumped, uniform or random, affected by the influence of abiotic, biotic or even random factors (Matteucci and Colma, 1982; Townsend et al., 2010; Freitas and Magalhães, 2014). The distribution pattern of tree species is a useful tool for the management strategy and / or conservation of a forest population or community (Freitas and Magalhães, 2014).

The aim of this study was to evaluate the floristic composition and the successional stage through the ecological groups and dispersal syndromes of the species present in a fragment of DSF in western Santa Catarina, and also to use the Shannon diversity $\left(\mathrm{H}^{\prime}\right)$, the Pielou evenness ( $\mathrm{J}$ ) and the McGinnies (IGA) indices to determine the species distribution pattern.

\section{Materials and Methods}

\section{Study Area}

The study was conducted in the Peixe river basin, between the cities of Ipira and Piratuba, both located in western Santa Catarina, between the coordinates $27^{\circ} 25^{\prime} 34^{\prime \prime}$ South and $51^{\circ} 47^{\prime} 18^{\prime \prime}$ West.

The predominant climate in the region is Mesothermal Humid Subtropical, Cfa (Köppen), with no distinct dry season. The monthly rainfall exceeds $60 \mathrm{~mm}$, with average temperatures of the warmest month above $22^{\circ} \mathrm{C}$ and the coldest month below $18^{\circ} \mathrm{C}$ and above $3^{\circ} \mathrm{C}$ (Seiffert and Perdomo, 1998).

The characteristic vegetation formation of this Upper Uruguay river region is the DSF (IBGE - Instituto Brasileiro de Geografia e Estatística, 1992), which extends throughout the valley of the Uruguay river, including the portion of the tributaries that is up to 500 - $600 \mathrm{~m}$ high.

\section{Field Procedure}

This study adopted the systematic sampling in tracks (IBGE 1992), using transects of $10 \times 100 \mathrm{~m}$, in a sampling of $1,000 \mathrm{~m}^{2}$, per transect. 14 transects were allocated throughout the area, totaling $14,000 \mathrm{~m}^{2}$ (1.4 ha).

In the tree layer, the height and the Circumference at Breast Height $(\mathrm{CBH})$, or $1.30 \mathrm{~m}$ above the ground, were measured for all trees with $\mathrm{CBH} \geq 12.57 \mathrm{~cm}$ (or $\mathrm{DBH} \geq 4.0 \mathrm{~cm}$ ), including the standing dead plants.

The taxonomic identification was carried out with the aid of specialized botanical literature and comparisons with the Herbarium Collection of the Federal University of 
Santa Catarina (UFSC). The validation of the names of species and the exclusion of synonyms were obtained through the website of Flora Brazil (2015). The adopted classification system for families was the APG III (2009), except for Fabaceae, which is divided in three subfamilies: Faboideae, Mimosoideae and Caesalpinoideae (Cronquist, 1981).

\section{Analysis Methods}

The species found in the examined fragment were also classified according to their successional stages. According to Budowski (1965), the pioneer species grow in clearings or open spaces, and they are clearly dependent on high light conditions. The early secondary species prefer environments such as small gaps or areas of old clearings, next to pioneer species, while the late secondary species have shown to be shade tolerant in the juvenile stage, forming understory seedlings banks, with great mortality of individuals in the early years, presenting small to medium sized seeds with low viability. The climax species grow slowly, they are light intolerant when adults, with a high number of individuals in natural regeneration, with seed of large and short viability.

The determination of the dispersal syndromes of each species was carried out. Following the categories proposed by Van Der Pijl (1957), species can be classified as: anemochoric (dispersed by the wind), zoochoric (dispersed by animals), autochoric (self-dispersion) and those without classification.

This study also applied the $\mathrm{H}^{\prime}$ and $\mathrm{J}$ indices (Brower and Zar, 1984), and the IGA index, which indicates that the distribution pattern is random when it is equal to one, uniform when it is below one, with tendency to cluster when it is above one and equal to or above two, and clumped when it is above two (McGinnies, 1934). The indices were calculated using Mata Nativa 3 (Cientec, 2012).

\section{Results}

This study recorded the presence of 2,125 individuals (2,754 stems), belonging to 34 botanical families, 83 genera and 113 species, disregarding the undetermined and dead individuals (Tab. 1).

The families presenting the highest species richness were Myrtaceae (16 or 14.2\%), Fabaceae - Faboideae (13 or 11.5\%), Euphorbiaceae (10 or $8.8 \%$ ), Lauraceae (8 or 7.1\%), Fabaceae - Mimosoideae and Rutaceae (6 or 5.3\% each).

Of the sampled individuals, $1,711(80.5 \%)$ are concentrated in only 10 botanical families, which are: Euphorbiaceae (297 or 14\% of individuals), Lauraceae (223 or $10.5 \%$ ), Meliaceae (204 or 9.6\%), Sapindaceae (168 or $7.9 \%$ ) Fabaceae - Faboideae (167 or $7.9 \%$ ), Salicaceae (162 or $7.6 \%$ ), Fabaceae - Mimosoideae (155 or $7.3 \%$ ), Malvaceae (142 or 6.7\%), Myrtaceae (138 or 6.5\%) and Apocynaceae (55 or 2.6\%). The other 550 individuals were distributed among the other 25 families.

In this study, the species with the greatest abundance were: A. concolor (146 individuals or $6.9 \%$ ), Luehea divaricata Mart. (142 individuals or 6.7\%), Casearia sylvestris Sw. (131), Cupania vernalis Cambess. (106), Parapiptadenia rigida (Benth.) Brenan (93), Guarea macrophylla Vahl (77), Cabralea canjerana (Vell.) Mart. (69), Nectandra megapotamica (Spreng.) Mez (69), Sebastiana commersoniana (Baill.) L.B. Sm. \& Downs (62), Ocotea puberula (Rich.) Nees (56) and Tabernaemontana catharinensis A. DC. (49), representing about $50 \%$ of all individuals. 
Table 1. Species sampled in a fragment of Deciduous Seasonal Forest in western Santa Catarina, Brazil, in alphabetical order.

\begin{tabular}{|c|c|c|c|c|c|c|}
\hline Scientific Name & BA & $\mathbf{N}_{\mathbf{i}}$ & $\mathbf{G A}_{\mathbf{I}}$ & Rating IGA & DS & EG \\
\hline Actiniostemon concolor (Spreng.) Müll. Arg. - EUPHORBIACEAE & 0.5532 & 146 & 15.05 & Clumped & AUT & LS \\
\hline Annona sp - ANNONACEAE & 0.4813 & 38 & 5.63 & Clumped & $\mathrm{ZOO}$ & ES \\
\hline Apuleia leiocarpa (Vogel) J. F. Macbr. - FABACEAE - CAES. & 19.952 & 36 & 2.64 & Clumped & ANE & CL \\
\hline Ateleia glazioveana Baill. - FABACEAE - FAB & 0.0315 & 2 & 2.5 & Clumped & ANE & PI \\
\hline Balfourodendron riedelianum (Engl.) Engl. - RUTACEAE & 0.0375 & 3 & 5.78 & Clumped & ANE & LS \\
\hline Brugmansia suaveolens (Bonpl. ex Willd.) Bercht. \& C. Presl - SOLANACEAE & 0.0472 & 9 & 3.71 & Clumped & AUT & $\mathrm{CL}$ \\
\hline Campomanesia guazumifolia (Camb.) O. Berg - MYRTACEAE & 0.0332 & 7 & 5.82 & Clumped & $\mathrm{ZOO}$ & LS \\
\hline Campomanesia sp. - MYRTACEAE & 0.0248 & 3 & 2.43 & Clumped & $\mathrm{ZOO}$ & LS \\
\hline Campomanesia xanthocarpa O. Berg - MYRTACEAE & 0.7213 & 45 & 2.07 & Clumped & $\mathrm{ZOO}$ & LS \\
\hline Casearia decandra Jacq. - SALICACEAE & 0.0612 & 19 & 2.89 & Clumped & $\mathrm{ZOO}$ & ES \\
\hline Casearia obliqua Spreng. - SALICACEAE & 0.2529 & 12 & 3.79 & Clumped & $\mathrm{ZOO}$ & $\mathrm{LS}$ \\
\hline Casearia sylvestris $\mathrm{Sw}$. - SALICACEAE & 12.897 & 131 & 4.03 & Clumped & $\mathrm{ZOO}$ & PI \\
\hline Cedrela fissilis Vell. - MELIACEAE & 0.2267 & 7 & 3.55 & Clumped & ANE & ES \\
\hline Celtis brasiliensis (Gardner) Planch. - CANNABACEAE & 0.0152 & 2 & 3.55 & Clumped & AUT & PI \\
\hline Citronella paniculata (Mart.) R.A. Howard - CARDIOPTERIDACEAE & 0.0241 & 1 & 2.06 & Clumped & $\mathrm{ZOO}$ & LS \\
\hline Cordia ecalyculata Vell. - BORAGINACEAE & 0.0092 & 1 & 2.59 & Clumped & $\mathrm{ZOO}$ & LS \\
\hline Dalbergia frutescens (Vell.) Britton - FABACEAE - FAB & 0.1248 & 14 & 7.35 & Clumped & ANE & PI \\
\hline Endlicheria paniculata (Spreng.) J.F. Macbr. - LAURACEAE & 0.4692 & 9 & 2.97 & Clumped & $\mathrm{ZOO}$ & LS \\
\hline Erythrina falcata Benth. - FABACEAE - FAB & 0.0964 & 2 & 2.67 & Clumped & ANE & $\mathrm{ES}$ \\
\hline Eugenia uniflora L. - MYRTACEAE & 0.0163 & 4 & 3.86 & Clumped & $\mathrm{ZOO}$ & ES \\
\hline Euphorbiaceae 1. - EUPHORBIACEAE & 0.0022 & 1 & 4.67 & Clumped & AUT & $\mathrm{NC}$ \\
\hline Hovenia dulcis Thunb. - RHAMNACEAE & 0.8689 & 48 & 6.49 & Clumped & AUT & CL \\
\hline Luehea divaricata Mart. - MALVACEAE & 51.292 & 142 & 2.36 & Clumped & ANE & $\mathrm{ES}$ \\
\hline Machaerium paraguariense Hassl. - FABACEAE - FAB & 0.2378 & 32 & 2.19 & Clumped & ANE & LS \\
\hline Machaerium sp. - FABACEAE - FAB & 0.0792 & 4 & 5.21 & Clumped & ANE & PI \\
\hline Machaerium stipitatum (DC.) Vogel - FABACEAE - FAB & 0.0353 & 8 & 2.7 & Clumped & ANE & ES \\
\hline Dead & 0.1872 & 10 & 4.12 & Clumped & - & \\
\hline Morus nigra L. - MORACEAE & 0.5523 & 43 & 3.86 & Clumped & $\mathrm{ZOO}$ & ES \\
\hline Myrciaria floribunda (H. West ex Willd.)O.Berg - MYRTACEAE & 0.0041 & 1 & 4.43 & Clumped & $\mathrm{ZOO}$ & LS \\
\hline Nectandra megapotamica (Spreng.) Mez - LAURACEAE & 10.305 & 69 & 8.8 & Clumped & $\mathrm{ZOO}$ & PI \\
\hline Ocotea diospyrifolia (Meisn.) Mez - LAURACEAE & 0.0685 & 8 & 4.72 & Clumped & $\mathrm{ZOO}$ & ES \\
\hline
\end{tabular}




\begin{tabular}{|c|c|c|c|c|c|c|}
\hline Scientific Name & BA & $\mathbf{N}_{\mathbf{i}}$ & $\mathbf{G A}_{\mathbf{I}}$ & Rating IGA & DS & EG \\
\hline Ocotea odorifera Rohwer - LAURACEAE & 0.9478 & 33 & 3.2 & Clumped & $\mathrm{ZOO}$ & LS \\
\hline Ocotea sp. - LAURACEAE & 0.3394 & 9 & 3.4 & Clumped & $\mathrm{ZOO}$ & $\mathrm{NC}$ \\
\hline Parapiptadenia rigida (Benth.) Brenan - FABACEAE - MIM. & 57.39 & 93 & 3.88 & Clumped & AUT & PI \\
\hline Picrasma crenata Engl. in Engl. \& Prantl - SIMAROUBACEAE & 0.0445 & 3 & 5.3 & Clumped & $\mathrm{ZOO}$ & LS \\
\hline Prunus myrtifolia (L.) Urb. - ROSACEAE & 0.2245 & 19 & 2.67 & Clumped & $\mathrm{ZOO}$ & PI \\
\hline Schinus terebinthifolia Raddi - ANACARDICEAE & 0.0158 & 5 & 2.32 & Clumped & $\mathrm{ZOO}$ & PI \\
\hline Sebastiania brasiliensis Spreng. - EUPHORBIACEAE & 0.1795 & 39 & 11.55 & Clumped & AUT & PI \\
\hline Sebastiania commersoniana (Baill.) L.B. Sm. \& Downs - EUPHORBIACEAE & 0.6654 & 62 & 10.02 & Clumped & $\mathrm{ZOO}$ & ES \\
\hline Strychnos brasiliensis (Spreng.) Mart. - LOGANIACEAE & 0.0771 & 6 & 2.78 & Clumped & $\mathrm{ZOO}$ & LS \\
\hline Syagrus romanzoffiana (Cham.) Glassman - ARECACEAE & 0.3002 & 7 & 2.07 & Clumped & $\mathrm{ZOO}$ & $\mathrm{ES}$ \\
\hline Tabernaemontana catharinensis A. DC. - APOCYNACEAE & 0.6876 & 49 & 2.27 & Clumped & $\mathrm{ZOO}$ & LS \\
\hline Terminalia australis Cambess. - COMBRETACEAE & 0.05 & 5 & 4.82 & Clumped & ANE & PI \\
\hline Trichilia claussenii C. DC. - MELIACEAE & 0.7544 & 47 & 4.84 & Clumped & $\mathrm{ZOO}$ & $\mathrm{CL}$ \\
\hline Urera baccifera (L.) Gaudich. ex Wedd. - URTICACEAE & 0.0196 & 7 & 3.24 & Clumped & $\mathrm{ZOO}$ & PI \\
\hline Vassobia breviflora (Sendtn.) Hunz. - SOLANACEAE & 0.023 & 6 & 2.78 & Clumped & $\mathrm{ZOO}$ & PI \\
\hline Zanthoxylum petiolare A. St.-Hil. \& Tul. - RUTACEAE & 0.0173 & 3 & 2.89 & Clumped & $\mathrm{ZOO}$ & ES \\
\hline Zanthoxylum rhoifolium Lam. - RUTACEAE & 0.0068 & 3 & 2.89 & Clumped & $\mathrm{ZOO}$ & PI \\
\hline Albizia edwallii (Hoehne) Barneby \& J.W. Grimes - FABACEAE - MIM & 0.1007 & 10 & 1.28 & Tend. Cluster & ANE & PI \\
\hline Albizia niopoides (Spruce ex Benth.) Burkart - FABACEAE - MIM & 0.0494 & 4 & 1.18 & Tend. Cluster & ANE & PI \\
\hline Alchornea triplinervia (Spreng.) Müll. Arg. - EUPHORBIACEAE & 0.305 & 3 & 1.39 & Tend. Cluster & $\mathrm{ZOO}$ & ES \\
\hline Boehmeria caudata Sw. - URTICACEAE & 0.0234 & 5 & 1.39 & Tend. Cluster & ANE & PI \\
\hline Cabralea canjerana (Vell.) Mart. - MELIACEAE & 19.576 & 69 & 1.48 & Tend. Cluster & $\mathrm{ZOO}$ & PI \\
\hline Calyptranthes tricona D. Legrand - MYRTACEAE & 0.1839 & 19 & 1.91 & Tend. Cluster & $\mathrm{ZOO}$ & $\mathrm{LS}$ \\
\hline Celtis iguanaea (Jacq.) Sarg. - CANNABACEAE & 0.0876 & 4 & 1.49 & Tend. Cluster & $\mathrm{ZOO}$ & PI \\
\hline Cestrum intermedium Sendtn. - SOLANACEAE & 0.0176 & 1 & 1.93 & Tend. Cluster & $\mathrm{ZOO}$ & ES \\
\hline Chrysophyllum gonocarpum (Mart. \& Eichler ex Miq.) Engl. - SAPOTACEAE & 0.2351 & 24 & 1.18 & Tend. Cluster & $\mathrm{ZOO}$ & CL \\
\hline Cinnamomum verum J. Presl - LAURACEAE & 0.0286 & 2 & 1.66 & Tend. Cluster & AUT & PI \\
\hline Citrus sp - RUTACEAE & 0.0875 & 16 & 1.93 & Tend. Cluster & $\mathrm{ZOO}$ & $\mathrm{NC}$ \\
\hline Coussarea contracta (Walp.) Müll. Arg. - RUBIACEAE & 0.0018 & 1 & 1.78 & Tend. Cluster & $\mathrm{ZOO}$ & LS \\
\hline Fabaceae 1 - FABACEAE - FAB & 0.0522 & 3 & 1.85 & Tend. Cluster & $\mathrm{ZOO}$ & $\mathrm{NC}$ \\
\hline Holocalyx balansae Micheli - FABACEAE - CAES & 0.0548 & 1 & 1.45 & Tend. Cluster & $\mathrm{ZOO}$ & PI \\
\hline
\end{tabular}




\begin{tabular}{|c|c|c|c|c|c|c|}
\hline Scientific Name & BA & $\mathbf{N}_{\mathbf{i}}$ & $\mathbf{G A}_{\mathbf{I}}$ & Rating IGA & DS & EG \\
\hline Jacaranda micrantha Cham. - BIGNONIACEAE & 0.0067 & 1 & 1.99 & Tend. Cluster & ANE & ES \\
\hline Maclura tinctoria (L.) D. Don ex Steud. - MORACEAE & 0.056 & 2 & 1.18 & Tend. Cluster & $\mathrm{ZOO}$ & ES \\
\hline Manihot grahamii Hook. - EUPHORBIACEAE & 0.0038 & 1 & 1.7 & Tend. Cluster & AUT & PI \\
\hline Myrcia oblongata DC. - MYRTACEAE & 0.002 & 1 & 1.62 & Tend. Cluster & $\mathrm{ZOO}$ & ES \\
\hline Myrsine umbellata Mart. - PRIMULACEAE & 0.0065 & 1 & 1.71 & Tend. Cluster & $\mathrm{ZOO}$ & PI \\
\hline Myrtaceae 3 - MYRTACEAE & 0.1063 & 4 & 1.93 & Tend. Cluster & $\mathrm{ZOO}$ & $\mathrm{NC}$ \\
\hline Nectandra lanceolata Nees - LAURACEAE & 0.9816 & 37 & 1.18 & Tend. Cluster & $\mathrm{ZOO}$ & LS \\
\hline Ocotea puberula (Rich.) Nees - LAURACEAE & 21.442 & 56 & 1.7 & Tend. Cluster & $\mathrm{ZOO}$ & ES \\
\hline Ruprechtia laxiflora Meisn. - POLYGONACEAE & 0.542 & 11 & 1.13 & Tend. Cluster & ANE & LS \\
\hline Sapium glandulosum (L.) Morong - EUPHORBIACEAE & 0.9342 & 33 & 1.53 & Tend. Cluster & $\mathrm{ZOO}$ & PI \\
\hline Solanum mauritianum Scop. - SOLANACEAE & 0.0514 & 2 & 1.93 & Tend. Cluster & $\mathrm{ZOO}$ & PI \\
\hline Trichilia elegans A. Juss. - MELIACEAE & 0.0081 & 4 & 1.18 & Tend. Cluster & $\mathrm{ZOO}$ & PI \\
\hline Vitex megapotamica (Spreng.) Moldenke - LAMIACEAE & 0.0186 & 4 & 1.85 & Tend. Cluster & $\mathrm{ZOO}$ & CL \\
\hline Aegiphila brachiata Velloso - LAMIACEAE & 0.004 & 1 & 0.96 & Uniform & $\mathrm{ZOO}$ & ES \\
\hline Allophylus edulis (A. St.-Hil., A. Juss. \& Cambess.) Hieron. ex Niederl. SAPINDACEAE & 0.1691 & 21 & 0.97 & Uniform & $\mathrm{ZOO}$ & PI \\
\hline Allophylus guaraniticus Radlk.- SAPINDACEAE & 0.0033 & 1 & 0.96 & Uniform & $\mathrm{ZOO}$ & ES \\
\hline Aloysia virgata (Ruiz \& Pav.) Pers. - VERBENACEAE & 0.0038 & 1 & 0.96 & Uniform & ANE & PI \\
\hline Aspidosperma australe Müll. Arg. - APOCYNACEAE & 0.0165 & 6 & 0 & Uniform & ANE & CL \\
\hline Bauhinia forficata Link - FABACEAE - FAB & 0.0583 & 8 & 0.93 & Uniform & AUT & PI \\
\hline Chrysophyllum marginatum (Hook. \& Arn.) Radlk. - SAPOTACEAE & 0.2617 & 20 & 0.96 & Uniform & $\mathrm{ZOO}$ & PI \\
\hline Cordia americana (L.) Gottschling \& J.S. Mill. - BORAGINACEAE & 0.8459 & 11 & 0.96 & Uniform & ANE & $\mathrm{CL}$ \\
\hline Coutarea hexandra (Jacq.) K. Schum. - RUBIACEAE & 0.002 & 1 & 0.96 & Uniform & $\mathrm{ZOO}$ & LS \\
\hline Cupania vernalis Cambess. - SAPINDACEAE & 11.032 & 106 & 0.96 & Uniform & $\mathrm{ZOO}$ & PI \\
\hline Dahlstedtia pinnata (Benth.) Malme - FABACEAE - FAB & 0.0024 & 1 & 0.96 & Uniform & AUT & ES \\
\hline Duranta vestita Cham. - VERBENACEAE & 0.0537 & 9 & 0.96 & Uniform & $\mathrm{ZOO}$ & CL \\
\hline Esenbeckia grandiflora Mart. - RUTACEAE & 0.0012 & 1 & 0.93 & Uniform & AUT & LS \\
\hline Eugenia burkartiana (D. Legrand) D. Legrand - MYRTACEAE & 0.032 & 5 & 0 & Uniform & $\mathrm{ZOO}$ & LS \\
\hline Eugenia rostrifolia D. Legrand - MYRTACEAE & 0.0012 & 1 & 0.96 & Uniform & $\mathrm{ZOO}$ & LS \\
\hline Eugenia sp - MYRTACEAE & 0.0179 & 4 & 0 & Uniform & $\mathrm{ZOO}$ & $\mathrm{LS}$ \\
\hline Eugenia subterminalis DC. - MYRTACEAE & 0.2524 & 22 & 0.96 & Uniform & $\mathrm{ZOO}$ & LS \\
\hline Ficus citrifolia Mill. - MORACEAE & 0.217 & 9 & 0.96 & Uniform & AUT & $\mathrm{ES}$ \\
\hline
\end{tabular}




\begin{tabular}{|c|c|c|c|c|c|c|}
\hline Scientific Name & BA & $\mathbf{N}_{\mathbf{i}}$ & $\mathbf{G A}_{\mathbf{I}}$ & Rating IGA & DS & EG \\
\hline Guarea macrophylla Vahl - MELIACEAE & 0.2771 & 77 & 0.89 & Uniform & $\mathrm{ZOO}$ & PI \\
\hline Inga marginata Willd. - FABACEAE - MIM & 0.4978 & 43 & 0 & Uniform & $\mathrm{ZOO}$ & PI \\
\hline Inga sp. - FABACEAE - MIMOSOIDEAE & 0.0013 & 1 & 0 & Uniform & $\mathrm{ZOO}$ & ES \\
\hline Julocroton sp. - EUPHORBIACEAE & 0.0015 & 1 & 0.96 & Uniform & AUT & $\mathrm{NC}$ \\
\hline Lonchocarpus nitidus (Vogel) Benth. - FABACEAE - FAB & 0.2733 & 28 & 0.96 & Uniform & ANE & ES \\
\hline Lonchocarpus sp. - FABACEAE - FAB & 0.1979 & 26 & 0.96 & Uniform & ANE & $\mathrm{NC}$ \\
\hline Matayba elaeagnoides Radlk. - SAPINDACEAE & 0.3925 & 40 & 0.93 & Uniform & $\mathrm{ZOO}$ & ES \\
\hline Mimosa bimucronata (DC.) Kuntze - FABACEAE - MIM & 0.0194 & 4 & 0.96 & Uniform & AUT & PI \\
\hline Myrocarpus frondosus Allemão - FABACEAE - FAB & 0.428 & 30 & 0.96 & Uniform & ANE & ES \\
\hline Myrsine sp. - PRIMULACEAE & 0.0012 & 1 & 0.96 & Uniform & $\mathrm{ZOO}$ & $\mathrm{NC}$ \\
\hline Myrtaceae 1 - MYRTACEAE & 0.0113 & 2 & 0.96 & Uniform & $\mathrm{ZOO}$ & $\mathrm{NC}$ \\
\hline Myrtaceae 2 - MYRTACEAE & 0.0035 & 1 & 0.96 & Uniform & $\mathrm{ZOO}$ & $\mathrm{NC}$ \\
\hline Myrtaceae 4 - MYRTACEAE & 0.074 & 19 & 0.96 & Uniform & $\mathrm{ZOO}$ & $\mathrm{NC}$ \\
\hline Poecilanthe parviflora Benth. - FABACEAE - FAB & 0.1629 & 9 & 0 & Uniform & AUT & LS \\
\hline Pouteria salicifolia (Spreng.) Radlk. SAPOTACEAE & 0.0494 & 1 & 0 & Uniform & $\mathrm{ZOO}$ & PI \\
\hline Ricinus communis L. - EUPHORBIACEAE & 0.0656 & 10 & 0.96 & Uniform & AUT & PI \\
\hline Sebastiania klotzschiana (Müll. Arg.) Müll. Arg. - EUPHORBIACEAE & 0.005 & 1 & 0.96 & Uniform & AUT & PI \\
\hline Sessea regnellii Taub. - SOLANACEAE & 0.0337 & 3 & 0.89 & Uniform & AUT & PI \\
\hline Trema micrantha (L.) Blume - CANNABACEAE & 0.0427 & 2 & 0.93 & Uniform & $\mathrm{ZOO}$ & PI \\
\hline Vasconcellea quercifolia A. St.-Hil. - CARICACEAE & 0.0199 & 1 & 0.96 & Uniform & $\mathrm{ZOO}$ & PI \\
\hline Zanthoxylum sp. RUTACEAE & 0.0754 & 2 & 0.93 & Uniform & $\mathrm{ZOO}$ & PI \\
\hline INDETERMINATE & 0.5861 & 23 & - & - & - & - \\
\hline TOTAL & 391.096 & 2.125 & - & - & - & - \\
\hline
\end{tabular}

BA: Basal Area $\left(m^{2} \times h^{-1}\right) ; N_{i}:$ number of individuals; GA $:$ Mc Ginnies index; Rating IGA; SD: dispersal syndrome; EG: ecological group 
With regard to the ecological groups, $40 \%$ of the individuals and $36.3 \%$ of the species were categorized as early individuals and late successional species, amounted to $22.1 \%$ and $23 \%$, respectively (Fig. 1). The zoochoric syndrome accounted for a little over $60 \%$ of individuals and species (Fig. 2).

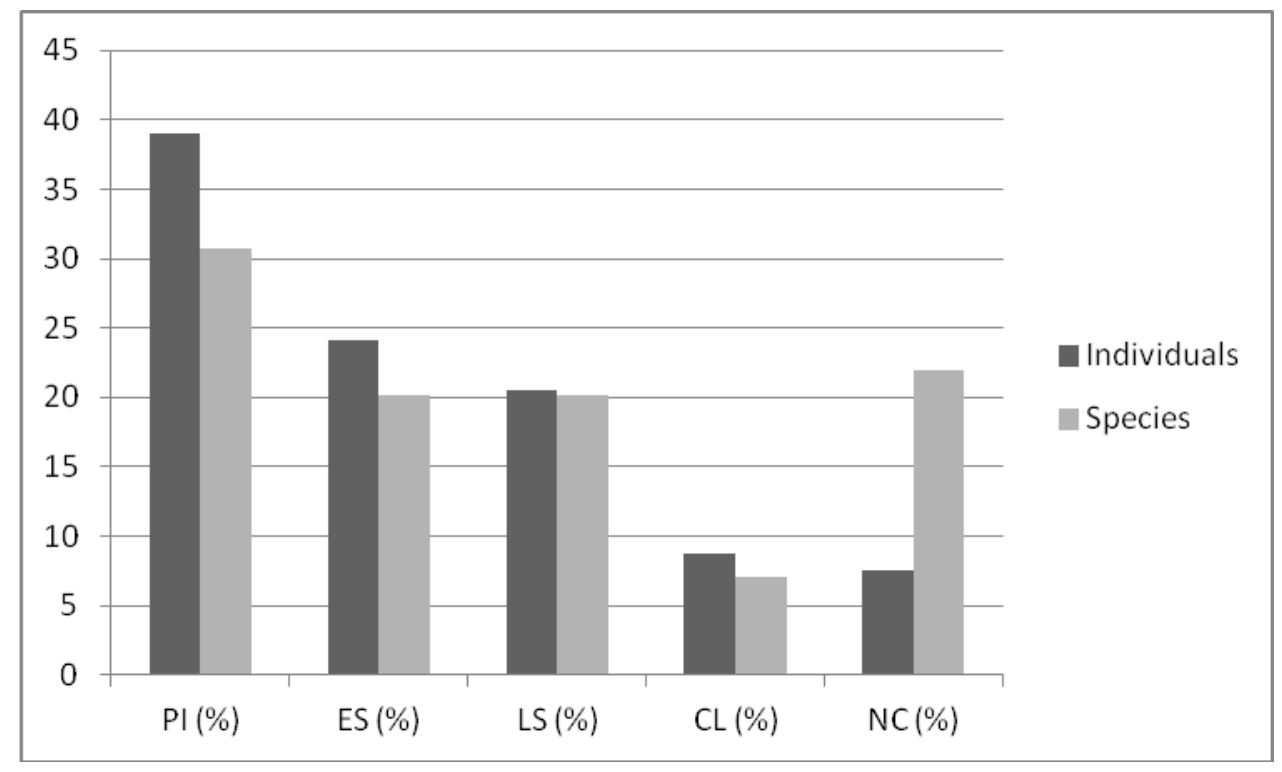

Figure 1. Frequency distribution of the number of individuals and species, according to ecological groups, in a deciduous seasonal forest fragment in western Santa Catarina, Brazil. CL - Climax; LS - Late Secondary; ES - Early Secondary; PI -Pioneer; NC - Not Classified.

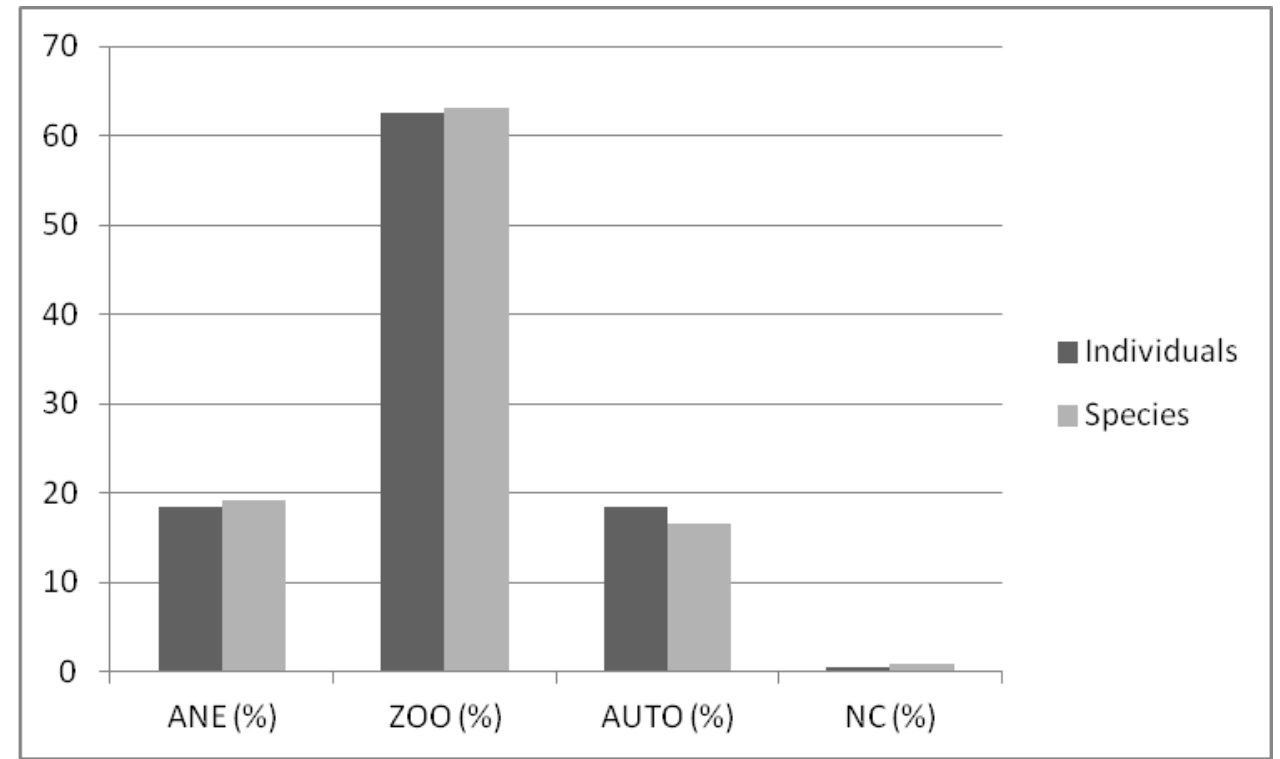

Figure 2. Frequency distribution of the number of individuals and species, according to the dispersal syndrome, in a deciduous seasonal forest fragment in western Santa Catarina, Brazil. ANE - Anemochoric; AUTO - Autochoric; ZOO - Zoochoric; NC - Not Classified. 
The $\mathrm{H}^{\prime}$ and the $\mathrm{J}$ were, respectively, 3.92 nats. ind ${ }^{-1}$ and 0.82 .

This community showed the predominance of a cluster spatial distribution pattern for a little over $40 \%$ of the species and for about $60 \%$ of the individuals (Fig. 3).

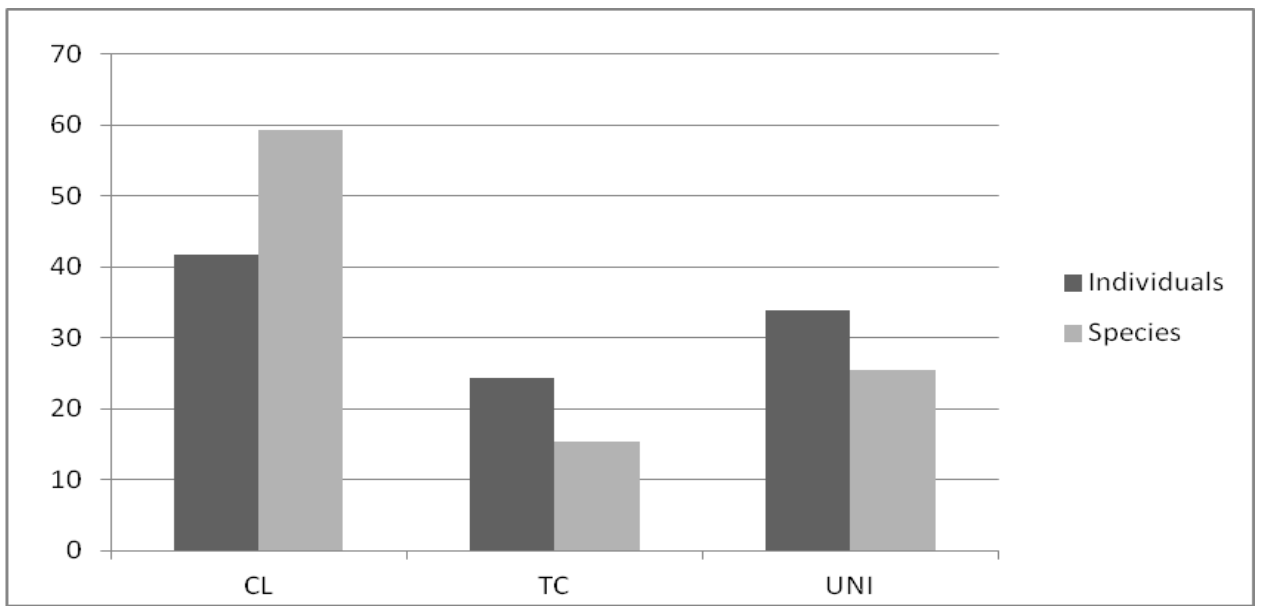

Figure 3. Frequency distribution of the number of individuals and species, according to McGinnies spatial distribution pattern, in a deciduous seasonal forest fragment in western Santa Catarina, Brazil. CL - Clumped; TC - Tendency to Cluster; UNI -Uniform.

This study recorded the presence of $11.6 \%$ of the species and $5.6 \%$ of the individuals considered exotic, such as: Cinnamomum verum J. Presl, Citrus sp, Hovenia dulcis Thunb. and Morus nigra L. (Flora Brasil, 2015). The species Brugmansia suaveolens (Bonpl. ex Willd.) Bercht. \& C. Presl (1.05\%) is considered a sub-spontaneous plant, also exotic, but that has adapted to the environment without causing adverse reactions in the community (Flora Brazil, 2015).

\section{Discussion}

The floristic comparisons between DSF remnants have shown that these areas are extremely diverse, with low similarity values, even between areas of high spatial proximity, and replacing the longitudinal distribution of deciduous formations (Prado and Gibbs, 1993; Oliveira-Filho and Fontes, 2000; Pennington et al., 2000; OliveiraFilho et al., 2006). Bolzon and Marchiori (2002) affirm that the deciduous and semideciduous forests are closely associated with the climate history of South America, started in the tertiary period, during the Pliocene.

According to Jasper et al. (2013), Santa Catarina's DSF structure has high species richness when compared to other seasonal forests, which may be associated with higher levels of rainfall in the regions where they occur, and a remarkable presence of widely distributed families and genera in neotropical dry forests.

The results corroborate that Myrtaceae and Fabaceae have a representative presence in many areas of DSF (Oliveira-Filho and Fontes, 2000). The Myrtaceae family has its participation justified by its broad longitudinal distribution spectrum (Negrelle, 2013). However, Gasper et al. (2013) claim that this family is best represented in the rain forests than in the seasonal forests, tending to decline in richness in the Cerrado and Amazon biomes. 
According to Ribeiro and Lima (2009) the Fabaceae (Leguminosae) family is more diversified in seasonal environments, which can be explained from the Tertiary, when the dry forests dominated the major regions of the world, from where the association of legumes with nitrogen-fixing bacteria created efficient evolutionary mechanisms, providing greater plasticity for the occupation in poor environments in nutrients and regeneration.

Five of the 10 species with the highest number of individuals recorded in this study were also cited by the Floristic and Forest Inventory of Santa Catarina (IFFSC) for the DSF, as follows: $O$. puberula, $N$. megapotamica, $L$. divaricata, $C$. vernalis and $C$. sylvestris (Vibrans et al., 2013). The species $C$. canjerana and $P$. rigida, common in DSF, are also present with relative abundance in the Dense Ombrophilous Forest (DOF) in Santa Catarina (Gasper et al., 2012; Gasper et al., 2013). For these authors, A. concolor is one of the main species in regenerating layers of DSF, but it rarely appears in DOF.

Some species found in this study are considered as having high timber value, as follows: Apuleia leiocarpa (Vogel) J. F. Macbr., C. canjerana, Nectandra lanceolata Nees, $P$. rigida and others (Fontana and Sevegnani, 2012).

According to Meyer et al. (2012), among the exotic species recorded in this study, only $\mathrm{H}$. dulcis demands further attention. According to these authors, this species occurs with relative abundance in Santa Catarina DSF, deserving greater monitoring in the recruitment process and occupation in forest fragments in the initial and intermediate stages, their typical colonization in environments, and to adopt measures for its management, due to its high potential for competition.

Approximately $25 \%$ of the abundance of the examined fragment was represented by pioneer species, as $N$. megapotamica, C. canjerana, G. macrophylla, $P$. rigida, $C$. vernalis and $C$. sylvestris. Nevertheless, the species $L$. divaricata (early secondary) and A. concolor (late secondary) amounted to almost $15 \%$ of the sampled tree individuals (Tab. 1).

The analysis of dispersal syndromes (Tab. 1) indicated that most species and individuals (a little over 60\%) use animals as dispersing agents, pattern already evidenced in several studies in the Atlantic Forest, as described by Almeida-Neto et al. (2008). As reported by Gentry (1982), the zoochory is the most important dispersal mode of woody species in the tropical region. In this sense, the community in question is very important for maintaining both its plant populations and the associated fauna.

Considering the participation of ecological groups and dispersal syndromes, it can be seen in the Table 1 that there is a significant participation of species and pioneer individuals in the study area. There is also a relatively large proportion of more demanding species concerning the quality of their habitats (late secondary and climax) and, at the same time, the associated fauna plays an important role in spreading seedlings. According to Carvalho (2010), forests in the initial stages have lower species richness with biotic dispersion in relation to the preserved forests, and little participation of zoochoric species. Given this hypothesis, it can be suggested that the community in question adds favorable conditions to evolve in successional stages, considering the biotic mechanisms involved in the maintenance of ecosystems.

According to the IFFSC, the examined fragment is highly relevant in terms of diversity and evenness, as their maximum values recorded for samples in Piratuba $(\mathrm{H} '=$ 3.13 nats. ind $^{-1}$ and $\left.J=0.63\right)$ and Ipira $\left(H^{\prime}=2.63\right.$ nats. ind $^{-1}$ and $\left.J=0.78\right)$ were lower than those found in this study $\left(\mathrm{H}^{\prime}=3.92\right.$ nats. ind $^{-1}$ and $\left.\mathrm{J}=0.82\right)$ (Vibrans et al., 2013). 
For this community, the level measured by the value of evenness $(\mathrm{J}=0.82)$ confirms the high value of $\mathrm{H}^{\prime}$. As stated by Werneck et al. (2000), high evenness values indicate more homogeneous abundance distribution among species and may be related to the high uniformity in the proportions of individuals in relation to the species within the community.

Oliveira-Filho and Fontes (2000) stated that Santa Catarina DSF establishes or provides a transition between the typical species from ombrophilous and seasonal environments, a fact that may be one of the arguments to explain the relative richness and diversity of species of Santa Catarina DSF.

Hay et al. (2000) consider three main scales: macro (biogeographical), meso (community) and micro (individuals within a community). The micro scale was considered in this study, restricted to the understanding of the distribution of species in a forest fragment of a small area (about $120 \mathrm{ha}$ ).

With respect to both individuals and species, a more uniform pattern was observed in the examined fragment, according to McGinnies index. Rondon Neto et al. (2000) report that the aggregation of tree species in tropical ecosystems may be associated to the kind of seeds dispersion, seeds sources distance, to variations in environmental conditions, particularly as regards their quality and intensity, in addition to the chemical and physical soil characteristics. For Silva et al. (2008), Cain et al. (2011), clusters indicate a mechanism of attraction, demonstrating that the chance of survival of an individual is increased by the presence of others of the same species or the availability of a common resource.

According to Fundação SOS Mata Atlântica and INPE (2015), deforestation rates in Ipira reduced 6\% in the period from 2013 to 2014, while in Piratuba numbers remained the same during the same period, suggesting that anthropogenic changes in the region have been at least controlled.

From these results, it can be assumed that the fragment in question is in successional transition phase, from the initial to the intermediate stage, considering the species richness and evenness, and biotic mechanisms as facilitators: the predominance of zoochory, the participation of more demanding species concerning the habitat quality (late secondary and climax) and the clumped distribution of species.

Thus, management measures adopted for a microscale, for example, the choice of species to enrich fragments or the identification of forest species matrices for seed collection may be taken towards the handling and storage repository for this important diversity. Such actions can have a positive impact in the short term, on alpha diversity, i.e., on the number of species in a fragment, and they may, in the medium term, contribute to beta diversity (diversity of habitats). Whittaker (1972) postulated that maintaining the alpha and beta diversity is fundamental to the success of the gamma diversity (regional diversity).

This study corroborates the assumption that the Santa Catarina DSF still presents forest remnants with high richness and diversity of species, such as the case of the analyzed fragment (113 species and $\mathrm{H}^{\prime}=3.92$ nats. ind $\left.{ }^{-1}\right)$. The studied fragment is in transition, from the initial to the intermediate stage, and it can be favored by biotic regulatory mechanisms, especially the zoochory and the clustered pattern distribution.

The application of McGinnies index can be of great use in the conservation and forest management, as their interpretation may contribute to the development of restoration methods of degraded areas, enrichment of forest remnants, germplasm conservation and other activities. 
Acknowledgements. To CAPES - Coordination for the Improvement of Higher Education Personnel for supporting to carry this work out. To UFRRJ - Federal Rural University of Rio de Janeiro - Part of Professor Welington Kiffer de Freitas Thesis.

\section{REFERENCES}

[1] Almeida-Neto, M., Campassi, F., Galetti, M., Jordano, P., Oliveira-Filho, A. (2008): Vertebrate dispersal syndromes along the Atlantic Forest: broad-scale patterns and macroecological correlates. - Global Ecology and Biogeography 17: 503-513.

[2] Angiosperm Phylogeny Group - APG III (2009): An update of the Angiosperm Phylogeny Group classification for the orders and families of flowering plants APG III. Botanical Journal of the Linnean Society 161: 105-121.

[3] Bolzon, R.T., Marchiori, J.N. (2002): A vegetação no sul da América: perspectiva paleoflorística. - Ciência \& Ambiente: 24: 05-24.

[4] Brower, J.E., Zar, J.H. (1984): Field and laboratory methods for general ecology. - Wm. C. Brown Publishers, Iowa.

[5] Budowski, G. (1965): Distribution of tropical American rain forest species in the light of successional processes. - Turrialba 15: 40-42.

[6] Cain, M.L., Bowman, W.D., Hacker, S.D. (2011): Ecologia. - Artmed, Porto Alegre.

[7] Carvalho, F.A. (2010): Síndromes de dispersão de espécies arbóreas de florestas ombrófilas submontanas do estado do Rio de Janeiro. - Revista Árvore 34: 1017-1023.

[8] Cientec. Mata Nativa 3: Sistema para Análise Fitossociológica, Elaboração de Inventários e Planos de Manejo de Florestas Nativas: Manual do usuário. - CIENTEC Ltda, Viçosa. http://www.cientec.net.br/br/ - Accessed 10 Mars 2015.

[9] Colombo, A.F., Joly, C.A. (2010): Brazilian Atlantic Forest lato sensu: the most ancient Brazilian forest, and a biodiversity hotspot, is highly threatened by climate change. Brazilian Journal of Biology 70: 697-708.

[10] Cronquist, A. (1981): An integrated system of classification of flowerinf plants. Columbia University Press, New York.

[11] Flora Brasil. Reflora: Lista de Espécies da Flora do Brasil. http://floradobrasil.jbrj.gov.br/jabot/listaBrasil/ConsultaPublicaUC/ConsultaPublicaUC.d o. Accessed 04 February 2015.

[12] Fontana, C., Sevegnani, L. (2012): Quais são as espécies arbóreas comuns da Floresta Estacional Decidual em Santa Catarina? - Revista de Estudos Ambientais 14: 74-88

[13] Freitas, W.K., Magalhães, L.M.S. (2012): Métodos e parâmetros para estudo da vegetação com ênfase no estrato arbóreo. - Floresta e Ambiente 19: 520-540.

[14] Freitas, W.K., Magalhães, L.M.S. (2014): Florística, diversidade e distribuição espacial das espécies arbóreas de um trecho de Floresta Estacional Semidecidual da Serra da Concórdia, RJ. - Floresta 44: 259-270.

[15] Fundação SOS Mata Atlântica, INPE - Instituto Nacional de Pesquisas Espaciais (2015): Atlas dos remanescentes florestais da Mata Atlântica, Período 2013-2014. Fundação SOS Mata Atlântica e São José dos Campos. - INPE, São Paulo.

[16] Fundação SOS Mata Atlântica, INPE - Instituto Nacional de Pesquisas Espaciais (2011): Atlas dos remanescentes florestais da Mata Atlântica, Período 2008-2010. Fundação SOS Mata Atlântica e São José dos Campos. - INPE, São Paulo.

[17] Gasper, A.L., Uhlmann, A., Vibrans, A.C., Sevegnani, L., Meyer, L. (2012): Grupos florísticos estruturais da Floresta Estacional Decidual em Santa Catarina. - In: Vibrans, A.C., Sevegnani, L., Gasper, A.L., Lingner, D.V. (ed.) Floresta Estacional Decidual: Inventário Florístico Florestal de Santa Catarina. - Edifurb, Blumenau.

[18] Gasper, A.L., Uhlmann, A., Sevegnan, L., Lingner, D.V., Rigon-Júnior, M.J., Verdi, M., Stival-Santos, A., Dreveck, S., Sobral, M., Vibrans, A.C. (2013): Inventário Florístico 
Florestal de Santa Catarina: espécies da Floresta Estacional Decidual. - Rodriguésia 64: 427-443.

[19] Gentry, A.H. (1982): Patterns of neotropical plant species diversity. - Evolution Biology 15: 1-84.

[20] Hay, J.D., Bizerril, M.X., Calouro, A.M., Costa, E.M.N., Ferreira, A.A., Gastal, M.L.A., Goes Junior, C.D., Manzan, D.J., Martins, C.R., Monteiro, J.M.G., Oliveira, S.A., Rodrigues, M.C.M., Seyffarth, J.A.S., Walter, B.M.T. (2000): Comparação do padrão da distribuição espacial em escalas diferentes de espécies nativas do cerrado, em Brasília, DF. - Revista Brasileira de Botânica 23: 341-347.

[21] IBGE - Instituto Brasileiro de Geografia e Estatística (1992): Manual técnico da vegetação brasileira. (Série Manuais Técnicos em Geociências n 1). - Fundação Instituto Brasileiro de Geografia e Estatística, Rio de Janeiro.

[22] Jasper, A., Guerra-Sommer M., Abu Hamad, A.M.B., Bamford, M., Oliveira, M.E.C.B., Tewari, R., Uhl, D. (2013): The Burning of Gondwana: Permian fires on the Southern Continent - a palaeobotanical approach. - Gondwana Research 24: 148-160.

[23] Matteucci, S.D., Colma, A. (1982): Metodologia para el estudio de la vegetacion. - The General Secretarial of the Organization of American States, Washington.

[24] McGinnies, W.G. (1934): The relationship between frequency index and abundance as applied to plant populations in a semi-arid region. - Ecology 16: 263-282.

[25] Meyer, L., Vibrans, A.C., Gasper, A.L., Lingner, D.V., Sampaio, D.K. (2012): Espécies exóticas encontradas nas florestas de Santa Catarina. - In: Vibrans, A.C., Sevegnani, L.; Gasper, A.L., Lingner, D.V. (ed.) Diversidade e conservação dos remanescentes florestais. - Edifurb, Blumenau.

[26] Negrelle, R.R.B. (2013): Composição e estrutura do componente arbóreo de remanescente de floresta estacional semidecidual aluvial no Pantanal Mato-Grossense, Brasil. - Revista Árvore 37: 989-999.

[27] Oliveira-Filho, A.T., Fontes, M.A.L. (2000): Patterns of floristic differentiation among Atlantic forests in southeastern Brazil and the influence of climate. - Biotropica 32: 793810.

[28] Oliveira-Filho, A.T., Jarenkow, J.A., Rodal, M.J.N. (2006): Floristic relationships of seasonally dry forests of eastern South America based on tree species distribution patterns. - In: Pennington, R.T., Lewis, G., Ratter, J.A. (ed.) Neotropical savannas and dry forests: plant diversity, biogeography and conservation. - CRC Press, Boca Raton.

[29] Pedreira, G., Sousa, H.C. (2011): Comunidade arbórea de uma mancha florestal permanentemente alagada e de sua vegetação adjacente em Ouro Preto-MG, Brasil. Ciência Florestal 21: 663-675.

[30] Pennington, R.T., Prado, D.E., Pendry, C.A. (2000): Neotropical seasonally dry forests and Quaternary vegetation changes. - Journal of Biogeography 27: 261-273.

[31] Prado, D.E., Gibbs, P.E. (1993): Patterns of species distributions in the dry seasonal forests of South America. Annals of the Missouri Botanical Garden 80: 902-927.

[32] Ribeiro, R.D., Lima, H.C. (2009): Riqueza e distribuição geográfica de espécies arbóreas da família Leguminosae e implicações para conservação no Centro de Diversidade Vegetal de Cabo Frio, Rio de Janeiro, Brasil. - Rodriguésia 60: 111-127.

[33] Ribeiro, M.C., Metzger, J.P., Martensen, A.C., Ponzoni, F.J., Hirota, M.M. (2009): The Brazilian Atlantic Forest: how much is left, and how is the remaining forest distributed? Implications for conservation. - Biological Conservation 142: 1141-1153.

[34] Rondon Neto, R.M., Botelho, S.A., Fontes, M.A.L., Davide, A.C., Faria, J.M.R. (2000): Estrutura e composição florística da comunidade arbustivo-arbórea de uma clareira de origem antrópica, em uma Floresta Estacional Semidecídua Montana, Lavras-MG, Brasil. - Cerne 6: 079-094.

[35] Santos, M.F., Serafim, H., Sano, P.T. Composição e estrutura arbórea em floresta estacional semidecidual no Espinhaço Meridional (Serra do Cipó, MG). - Rodriguésia 63: 985-997. 
[36] Seiffert, N.F., Perdomo, C.C. (1998): Aptidão de solos da bacia hidrográfica do rio do Peixe para aporte de fertilizantes orgânicos. - Embrapa Suínos e Aves, Concórdia.

[37] Silva, M.A., Mello, J.M., Scolforo, J.R.S., Czanck Júnior, L., Andrade, I.S., Oliveira, A.D. (2008): Análise da distribuição espacial da candeia (Eremanthus erythropappus (DC.) MacLeish) sujeita ao sistema de manejo porta-sementes. - Cerne 14: 311-316.

[38] Townsend, C.R., Begon, M., Harper, J.L. (2010): Fundamentos em ecologia. - Artmed, Porto Alegre.

[39] Van Der Pijl, L. (1957): The dispersal of plants by bats (chiropterochory). - Acta Botanica Neerlandica 6: 291-315.

[40] Vibrans, A.C., Sevegnani, L., Gasper, A.L., Müller, J.J.V., Reis, M.S. (2013): Inventário florístico florestal de Santa Catarina: resultados resumidos. - FURB / CCA-UFSC / Epagri, Blumenau.

[41] Vibrans, A.C., Uhlmann, A., Sevegnani, L., Marcolin, M., Nakajima, N., Grippa, C.R., Brogni, E., Godoy, M.B. (2008): Ordenação dos dados de estrutura da Floresta Ombrófila Mista partindo de informações do Inventário Florístico-Florestal de Santa Catarina: resultados de estudo-piloto. - Ciência Florestal 18: 511-523.

[42] Werneck, M.S., Pedralli, G., Koenig, R., Giseke, L.F. (2000): Florística e estrutura de três trechos de uma floresta semidecídua na Estação Ecológica do Tripuí, Ouro Preto, MG. - Revista Brasileira de Botânica 23: 97-106.

[43] Whittaker, R.H. (1972): Evolution and measurement of species diversity. - Taxon 21: 213-251. 